\title{
The preoperative management of dabigatran and its specific antidote idarucizumab in patients with nonvalvular atrial fibrillation - case reports
}

\author{
Milan Tomić ${ }^{1}$ \\ ${ }^{1}$ Clinical Center of Serbia, 11000 Belgrade, Republic of Serbia
}

Corresponding author: Milan Tomić, e-mail: lane.tomic@gmail.com

\begin{abstract}
Summary
Dabigatran is a novel oral anticoagulant preferred due to its ease of use, favorable pharmacokinetics, decreased potential for drug-drug interactions, and the lack of monitoring requirements. With the growing use of dabigatran, it is important to highlight that dabigatran increases the risk of hemorrhage after some procedures. Therefore, when dabigatran is used before the elective or urgent procedures, it is necessary to compare the thromboembolic event risk with the relative risk of bleeding. Before the approval of a reversal agent, the lack of specific antidotes had been the major limitation against the widespread utilization of dabigatran. In October 2015, idarucizumab, a humanized monoclonal antigen-binding antibody fragment capable of reversing the anticoagulant activity of dabigatran, has been introduced into the market to be used in lifethreatening bleeding or urgent surgery. In this manuscript, the preoperative management of dabigatran and the initial experience of using idarucizumab in a patient with nonvalvular atrial fibrillation were described. We propose that the option of dabigatran reversal needs to be considered in patients with nonvalvular atrial fibrillation. However, additional research is needed to define optimal perioperative management of dabigatran and other novel oral anticoagulants, especially in high bleeding risk patients, and to determine whether pre-procedure coagulation testing should be performed.
\end{abstract}

Keywords: novel oral anticoagulants (NOACs), dabigatran, idarucizumab, atrial fibrillation 


\section{Introduction}

Vitamin K antagonists, such as warfarin, have been the anticoagulants of choice for many years for patients with atrial fibrillation (AF) and other thrombotic conditions. The introduction of novel oral anticoagulants (NOACs) as alternatives to the long-standing anticoagulant therapy represents a major advance. NOACs are found to be at least as safe and effective as vitamin $\mathrm{K}$ antagonists in randomized controlled trials for stroke prevention in AF and the management of venous thromboembolism (VTE). Four NOACs, dabigatran, rivaroxaban, apixaban, and edoxaban, have been approved for stroke prevention in AF. Unlike the factor Xa inhibitors, rivaroxaban, apixaban, and edoxaban, dabigatran is a direct thrombin inhibitor (1). Betrixaban, also known as Bevyxxa ${ }^{\circledR}$, is the newest NOAC on the market. It's similar to other NOACs, but it is specifically approved for the prophylaxis of VTE in adult patients hospitalized for an acute medical illness who are at risk for thromboembolic complications (2).

Dabigatran etexilate (Pradaxa ${ }^{\circledR}$ ) is the first specific and reversible direct thrombin inhibitor approved for stroke prevention in patients with AF and the treatment of VTE (3). Dabigatran etexilate is administered orally as a prodrug. By inhibiting thrombin, the final step of the clotting cascade, it impairs fibrinogen conversion to fibrin and prevents stabilization of thrombus formation (4). Unlike warfarin, dabigatran has a quicker onset and offset of action, does not require routine monitoring of coagulation parameters, and has less potential for drug-drug interactions (5). With the growing use of dabigatran, it is important to consider that dabigatran increases the risk of hemorrhage after some procedures. For patients taking dabigatran who require invasive or surgical procedures, it is necessary to compare the thromboembolic event risk with the relative risk of bleeding. Due to an increased risk of bleeding, dabigatran should be discontinued before invasive or surgical procedures, if possible, 1-2 days when creatinine clearance $(\mathrm{CrCl}) \geq 50 \mathrm{ml} / \mathrm{min}$, or 3-5 days when $\mathrm{CrCl}<50 \mathrm{ml} / \mathrm{min}$. For patients undergoing major surgery, spinal puncture, or placement of a spinal epidural catheter or port, in whom complete hemostasis may be required, longer times should be considered. However, it should be taken into consideration that premature discontinuation of dabigatran, in the absence of adequate alternative anticoagulation increases the risk of thrombotic events (3).

In case of emergency surgery or urgent procedures or cases of unexpected trauma, the risk of bleeding should be weighed against the urgency of intervention (3). The lack of specific antidotes and the lack of availability of laboratory testing to determine the degree of anticoagulation activity of dabigatran had been the major limitation against the widespread utilization of dabigatran (6,7). Prior to the approval of a reversal agent, the therapy for major bleeding while on dabigatran consisted of discontinuation of the agent, local bleeding control measures, blood transfusions, activated charcoal (in cases of recent ingestion), and hemostatic therapy (plasma, vitamin $\mathrm{K}$, factor concentrates, cryoprecipitate, platelets) (7). 
In October 2015, the US Food and Drug Administration (FDA) approved idarucizumab (Praxbind ${ }^{\circledR}$ ) as the first specific reversal agent for dabigatran, indicated for patients with life-threatening or uncontrolled bleeding, as well as in cases where rapid reversal is needed for urgent and emergent procedures. Idarucizumab is a humanized monoclonal antibody fragment that binds the thrombin-binding site of dabigatran with high affinity, effectively neutralizing its anticoagulant effects (3). Idarucizumab binds dabigatran with high specificity and could present an attractive therapeutic option for reversing the effects of dabigatran without directly affecting natural anticoagulation processes (8). It is administered intravenously as two separate $2.5 \mathrm{~g}$ doses (administered no more than 15 minutes apart) for emergency surgical procedures or life-threatening, uncontrolled bleeding in patients receiving dabigatran for anticoagulation (3). Idarucizumab administration may be conducted in any settings based on emergent need and should occur in conjunction with hemostatic agents, such as blood products, plasma derivatives, volume expanders, albumin, and others (9). The safety, efficacy, and tolerability of idarucizumab in the reversal of dabigatran-induced anticoagulation have been assessed in several clinical trials $(10,11,12)$.

The complexity of drug therapies, multiple drug regimens, and the occurrence of medication errors require a close collaboration between doctors and pharmacists within hospital settings, which could significantly improve the rational use of medicines and patient care, especially for patients with chronic illnesses and/or requiring regular medication reviews.

\section{Experimental part (Case reports)}

\section{Case 1}

A 75-year-old woman with a past medical history significant for AF, cardiac insufficiency, hypertension, and chronic gastritis was admitted to Emergency Center and prepared for elective laparoscopic cholecystectomy. The patient had been taking dabigatran $150 \mathrm{mg}$ twice daily, amiodarone $200 \mathrm{mg}$ twice daily, digoxin, and ramipril were prescribed for the treatment of cardiac insufficiency, arrhythmia, and hypertension. A physical examination and laboratory testing were performed at admission. Upon examination, the patient was found to be hypertensive (blood pressure, BP, 160/120 mm $\mathrm{Hg}$ ) with $\mathrm{CrCl} 55 \mathrm{~mL} / \mathrm{min}$. In most patients with normal renal function, dabigatran's anticoagulant effect is mostly gone within 1 to 2 days after the last dose has been taken, as approximately $80-85 \%$ of the drug is excreted by the kidney relatively quickly. Therefore, since the half-life in individuals with normal renal function is 12 to 14 hours, it is advisable to stop the dabigatran therapy 1-2 days before the procedure. However, in patients with impaired renal function half-life is prolonged (approximately 18 hours), and dabigatran must be discontinued earlier, usually 2-3 days before the procedure. 
The pharmacist was called upon for assistance with anticoagulation management in this 75-year-old woman on dabigatran who needs interruption of therapy for an elective laparoscopic cholecystectomy. In this specific patient, the collaboration between the pharmacist and medical staff made the decision-making process more efficient. The timepoint before a procedure that a patient should take the last dose of dabigatran depends on the type of procedure, whether the patient is at high or low risk for thrombosis while off anticoagulants, and the patient's renal function. Also, in our laboratory activated partial thromboplastin time (aPTT) and thrombin time (TT) are available as tests to provide a qualitative assessment of dabigatran. Due to its limited sensitivity, aPTT is not suitable for quantification of the anticoagulant effect of dabigatran, especially at high concentrations, and can only be useful as a screening assay, with some limitations. Upon admission, a patient had a prolonged aPTT and TT which implied the presence of dabigatran in the plasma. However, diluted thrombin time (dTT) and ecarin clotting time (ECT) tests provide the best correlation with plasma concentration and are recommended for accurate quantitative measurement of dabigatran concentrations (13).

The surgeon decided that dabigatran therapy should be stopped 2 days before the procedure, according to the guidelines. One day before the surgery, the aPTT and TT tests were performed, and the results were different. Prolonged aPTT value could be due to the presence of trough-like or greater concentrations of dabigatran. However, a normal TT indicated the absence of dabigatran in significant concentrations. The patient underwent the procedure without complications. The next day the patient was discharged from the intensive care unit completely oriented and able to understand the information about her procedure. The laboratory tests were again performed and indicated that anticoagulant therapy could be continued. Therefore, the doctor and pharmacist agreed to resume dabigatran (150 mg twice daily) 24 hours after the surgery.

\section{Case 2}

Here, we report the case of a 74-year-old male patient with nonvalvular AF who was taking dabigatran $(2 \times 110 \mathrm{mg})$. This patient was admitted to the Emergency Center after a traffic accident and required an urgent surgical procedure. It was not known whether he took the medicine, but the surgeon was worried about the possibility that dabigatran could cause full anticoagulation. Before every decision, laboratory testing was routinely performed. TT and aPTT tests were available as screening assays. aPTT was not adequate for quantification of the anticoagulant effect of dabigatran, and we could not perform dTT tests for accurate quantitative measurement of dabigatran. aPTT value was in agreement with the normal values $(\mathrm{aPTT}=34 \mathrm{~s})$ since the reference range of the aPTT was 21-35 $\mathrm{s}$ in our laboratory. TT assay was performed immediately upon admission and the value was $29 \mathrm{~s}$, which was outside the reference range (15-19s). Therefore, the second TT assay was repeated after 4 hours, and the obtained TT value was $25 \mathrm{~s}$. Elevated TT values indicated the presence of dabigatran in the plasma but could not provide 
quantitative information on dabigatran activity. This challenging decision demanded more consideration and the pharmacist was called upon for assistance before the procedure. After the consultation, a decision was made to administer idarucizumab for achieving a complete reversal of any potential anticoagulant effect of dabigatran. Idarucizumab is authorized in Serbia, but it is on a negative list which specifies those drugs doctors cannot prescribe at the expense of the national health insurance fund. However, the Emergency Center could supply idarucizumab to healthcare professionals to distribute to patients in case of urgent surgical procedures.

The patient received a $5 \mathrm{~g}$ dose of idarucizumab, provided as two separate vials each containing $2.5 \mathrm{~g} / 50 \mathrm{~mL}$ idarucizumab, and underwent the procedure without complications. Further, the patient was transferred to the surgical intensive care unit for observation. It was recommended the use of prophylactic-dose of low-molecular-weight (LMW) heparin for VTE prophylaxis for the first two to three postoperative days. When the absence of hemorrhage was confirmed, the anticoagulant therapy with dabigatran 100 mg twice daily was resumed.

\section{Discussion}

Antithrombotic therapy is used to reduce the risk of thromboembolic events in patients with conditions such as AF and VTE. Common adverse events of antithrombotic therapy include gastrointestinal bleeding, and their use increases the risk of hemorrhage after some endoscopic interventions. Endoscopic procedures vary in their potential to induce bleeding. Traditionally, low-risk procedures include diagnostic EGD, colonoscopy, ERCP without sphincterotomy, biliary stent placement, and push or balloon-assisted enteroscopy. High-risk endoscopic procedures are associated with a potential for bleeding that requires an intervention, such as hospitalization, transfusion, endoscopic treatment, or surgery. For patients taking dabigatran who require endoscopic procedures, various factors should be considered, such as: the urgency of the procedure, the bleeding risk of the procedure, the effect of dabigatran on the bleeding risk, and the risk of a thromboembolic event related to the periprocedural interruption of antithrombotic agents. The probability of a thromboembolic event related to the temporary interruption of antithrombotic therapy for an endoscopic procedure depends on the indication for antithrombotic therapy and individual patient characteristics (14). Several studies have confirmed that in patients receiving dabigatran who require an elective procedure, a standardized interruption protocol yielded $80-86 \%$ of patients with no residual anticoagulant effect at the time of the procedure, and with a low incidence of bleeding (15).

However, if a patient requires an urgent invasive procedure associated with an increased risk of bleeding or in cases of unexpected trauma, it is advisable to confirm no residual anticoagulant effect before the procedure. The qualitative assessment could identify the presence of anticoagulants. The quantitative assessment of drug concentration 
or anticoagulant activity could weigh the risk of bleeding against the risk of delaying the procedure (16). aPTT is a widely used routine clotting assay performed to determine the bleeding or clotting tendency of blood. However, the Summary of product characteristics (SmPC) for dabigatran highlights the limited sensitivity of this test to dabigatran, making it unsuitable for precise quantification of anticoagulant effect, particularly at high dabigatran concentrations. Dabigatran can also falsely elevate prothrombin time (PT) and international normalized ratio (INR), which reduces the clinical utility of these results (4). The PT and aPTT are laboratory tests commonly used to monitor warfarin and heparin and have limitations for measuring dabigatran anticoagulant activity. Therefore, a normal PT and/or aPTT may not exclude clinically relevant anticoagulant effects of dabigatran. On the other hand, a normal TT could exclude clinically relevant drug concentrations (17). For accurate quantitative measurement of dabigatran concentrations, diluted thrombin time (dTT) tests (such as Hemoclot ${ }^{\circledR}$, Technoview $^{\circledR}$, or Hemosil ${ }^{\circledR}$ ) are recommended. The ecarin clotting time (ECT) assay provides a direct measure of dabigatran activity, but it is not routinely available (18). Therefore, in situations of lifethreatening bleeding or urgent surgery, the immediate reversal of dabigatran-induced anticoagulation by idarucizumab can rapidly normalize clotting parameters and avoid morbidity (13).

\section{Conclusions}

In patients with AF who require interruption of dabigatran for an elective procedure, a standardized interruption protocol for dabigatran confirms no residual anticoagulant effect before the procedure. However, additional research is needed to define optimal perioperative management of dabigatran and other NOACs, especially in high bleeding risk patients, and to determine whether pre-procedure coagulation testing should be performed.

In case 2, we presented for the first time the use of idaricuzumab for dabigatran reversal in the patient with nonvalvular AF at the Emergency Center. It was demonstrated that dabigatran reversal is well tolerated without any complications occurred, but further studies are mandatory to confirm the safety profile of idarucizumab for this purpose.

In a summary, institutions should develop clinical protocols for treating patients with dabigatran-related bleeding and it is of the utmost importance to establish a closer collaboration between doctors and pharmacists within hospital settings, which could have a profound impact on patients' health. 


\section{Additional Information}

\section{Disclosures}

\section{Human subjects}

Consent was obtained by all participants in this study.

\section{Conflicts of interest}

The author declared no conflicts of interest.

\section{References}

1. Sikorska J, and Uprichard J. Direct oral anticoagulants: A quick guide. Eur Cardiol. 2017;12(1):405 .

2. Huisman MV, Klok FA. Pharmacological properties of betrixaban. Eur Heart J Suppl. 2018;20(Suppl E):E12-E15.

3. Praxbind (idarucizumab) injection for intravenous use prescribing information. Ridgefield, Connecticut: Boehringer Ingelheim Pharmaceuticals, Inc.;October 2015. https://www.accessdata.fda.gov/drugsatfda_docs/label/2015/761025lbl.pdf (last accessed: 23/10/2020)

4. Leung TS, Fradette M, Thompson A, et al. Dabigatran in atrial fibrillation: New kid on the block. Can Pharm J (Ott). 2012;145(2):83-7.e1.

5. Connolly SJ, Ezekowitz MD, Yusuf S, et al. Dabigatran versus warfarin in patients with atrial fibrillation. N Engl J Med. 2009;361(12):1139-51.

6. Eby C. Novel anticoagulants and laboratory testing. Int J Lab Hematol 2013;35:262-8.

7. Eerenberg ES, Kamphuisen PW, Sijpkens MK, et al. Reversal of rivaroxaban and dabigatran by prothrombin complex concentrate: a randomized, placebo-controlled, crossover study in healthy subjects. Circulation. 2011;124(14):1573-9.

8. Pollack CV, Reilly PA, Eikelboom J, et al. Idarucizumab for dabigatran reversal. N Engl J Med. 2015;373(6):511-20.

9. Pollack CV, Reilly PA, van Ryn J, et al. Idarucizumab for dabigatran reversal-full cohort analysis. N Engl J Med. 2017;377(5):431-41. 
10. Glund S, Stangier J, Schmohl M, et al. Safety, tolerability, and efficacy of idarucizumab for the reversal of the anticoagulant effect of dabigatran in healthy male volunteers: a randomised, placebocontrolled, double-blind phase 1 trial. Lancet. 2015;386(9994):680-90.

11. Glund S, Moschetti V, Norris S, et al. A randomised study in healthy volunteers to investigate the safety, tolerability and pharmacokinetics of idarucizumab, a specific antidote to dabigatran. Thromb Haemost. 2015;113(05):943-51.

12. Reilly P, van Ryn J, Grottke O, et al. Idarucizumab, a specific reversal agent for dabigatran: mode of action, pharmacokinetics and pharmacodynamics, and safety and efficacy in phase 1 subjects. Am J Med. 2016;129(Suppl 11):S64-S72.

13. Husted S, Verheugt FW, Comuth WJ. Reversal strategies for NOACs: state of development, possible clinical applications and future perspectives. Drug Saf. 2016;39:5-13.

14. ASGE Standards of Practice Committee; Acosta RD, Abraham NS, Chandrasekhara V, et al. The management of antithrombotic agents for patients undergoing GI endoscopy Gastrointest Endosc. 2016;83(1):3-16.

15. Douketis JD, Wang G, Chan N, et al. Effect of standardized perioperative dabigatran interruption on the residual anticoagulation effect at the time of surgery or procedure. J Thromb Haemost. 2016;14(1):89-97.

16. Garcia D, Barrett YC, Ramacciotti E, et al. Laboratory assessment of the anticoagulant effects of the next generation of oral anticoagulants. J Thromb Haemost. 2013.11(2):245-52.

17. Cuker A, Deborah M, Siegal DM , et al. Laboratory measurement of the anticoagulant activity of the target-specific oral anticoagulant agents: a systematic review. J Am Coll Cardiol. 2014;64(11):11281139.

18. Ten Cate H, Henskens Y, Lancé MD. Practical guidance on the use of laboratory testing in the management of bleeding in patients receiving direct oral anticoagulants. Vasc Health Risk Manag. 2017;13:457-67. 


\title{
Preoperativna primena dabigatrana i njegovog specifičnog antidota idarucizumaba kod pacijenata sa nevalvularnom atrijalnom fibrilacijom
}

\author{
Milan Tomić ${ }^{1}$ \\ ${ }^{1}$ Klinički centar Srbije, 11000 Beograd, Republika Srbija
}

Autor za korespondenciju: Milan Tomić, e-mail: lane.tomic@gmail.com

\begin{abstract}
Kratak sadržaj
Dabigatran je rado korišćen novi oralni antikoagulantni lek pre svega zbog lakoće upotrebe, povoljnog farmakokinetičkog profila, smanjene verovatnoće za interakcije sa drugim lekovima, kao i zbog toga što ne zahteva rutinsko praćenje antikoagulacije. Sa sve većom primenom dabigatrana, važno je uzeti u obzir da on povećava rizik od krvarenja nakon nekih intervencija. Stoga, kada se koristi pre elektivnih ili hitnih intervencija, potrebno je uporediti rizik od tromboembolijskih događaja sa relativnim rizikom od krvarenja. Pre nego što je odobren, nedostatak specifičnog antidota bio je glavna prepreka širokoj upotrebi dabigatrana. U oktobru 2015. godine, na tržištu je predstavljen idarucizumab, fragment humanizovanog monoklonskog antitela koji može da preokrene antikoagulantnu aktivnost dabigatrana i koji se koristi u krvarenjima opasnim po život ili hitnim interverncijama.

Ovde je opisana preoperativna primena dabigatrana, naše početno iskustvo sa upotrebom idarucizumaba kod pacijenata sa nevalvularnom atrijalnom fibrilacijom i predlog da se razmotri mogućnost reverzije antikoagulacionog dejstva dabigatrana kod ovih pacijenata. Međutim, potrebna su dodatna istraživanja kako bi se definisala optimalna perioperativna primena dabigatrana i ostalih novih oralnih antikoagulantnih lekova, posebno kod pacijenata sa visokim rizikom od krvarenja, i kako bi se utvrdilo da li je potrebno preoperativno sprovesti određene testove koagulacije.
\end{abstract}

Ključne reči: novi oralni antikoagulansi (NOAK), dabigatran, idarucizumab, atrijalna fibrilacija 